\title{
The monstrosity of humiliation: an ethnography among women who've been attacked with chemicals
}

A monstruosidade da humilhação:uma etnografia entre mulheres agredidas com agentes químicos ${ }^{1}$

\section{María Elvira Díaz-Benítez}

\section{(2) OpenEdition} Journals

\section{Electronic version}

URL: https://journals.openedition.org/aa/8920

DOI: 10.4000/aa.8920

ISSN: 2357-738X

\section{Publisher}

Programa de Pós-Graduação em Antropologia Social (UnB)

\section{Printed version}

Number of pages: 207-226

ISSN: 0102-4302

\section{Electronic reference}

María Elvira Díaz-Benítez, "The monstrosity of humiliation: an ethnography among women who've been attacked with chemicals", Anuário Antropológico [Online], v.46 n.3 | 2021, Online since 28 September 2021, connection on 01 October 2021. URL: http://journals.openedition.org/aa/8920 ; DOI: https://doi.org/10.4000/aa.8920

\section{(c) (i) (9)}

Anuário Antropológico is licensed under a Creative Commons Atribuição-Uso Não-Comercial-Proibição de realização de Obras Derivadas 4.0 International. 
The Monstrosity of Humiliation: An ethnography among women who've been attacked with chemicals María Elvira Díaz-Benítez

\section{(2) OpenEdition \\ Journals}

\section{Edição electrônica}

URL: http://journals.openedition.org/aa/8920

DOI: $10.4000 / a a .8920$

ISSN: 2357-738X

\section{Editora}

Programa de Pós-Graduação em Antropologia Social (UnB)

\section{Referência eletrônica}

María Elvira Díaz-Benítez, «The Monstrosity of Humiliation: An ethnography among women who've been attacked with chemicals», Anuário Antropológico [Online], v.46 n.3| 2021. URL: http://journals. openedition.org/aa/8920; DOI: https://doi.org/10.4000/aa.8920

\section{(6) $\Theta \Theta \Theta$}

Anuário Antropológico is licensed under a Creative Commons. Atribuição-SemDerivações-SemDerivados CCBY-NC-ND 


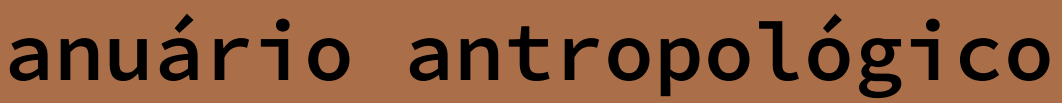 \\ (c) (i) \\ v. $46 \cdot n^{0} 3 \cdot$ setembro-dezembro $\cdot 2021.3$
}

\section{The monstrosity of humiliation: an ethnography among women who've been attacked with chemicals ${ }^{1}$}

DOI: https://doi.org/10.4000/aa.8920

\author{
María Elvira Díaz-Benítez \\ Museu Nacional / Universidade Federal do Rio de Janeiro, Pós-Graduação em Antropolo- \\ gia Social, Departamento de Antropologia, Rio de Janeiro, RJ - Brasil \\ Professor at the Programa de Pós-Graduação em Antropologia Social do Museu Nacional, UFRJ.
}

Based on ethnography in Colombia among women who had chemical agents tossed in their faces, I argue that this act marks and amputates faces in particular as a way of leaving the victim alive, but sub-humanized, ashamed, and removed from social life. I analyze the initial effects of this act as an undoing, as an act that affects and alters relationships and the very perception that the subject has of themselves; as a humiliation that seeks to be ever renewed, stretching through time as a visible scar; as a tool for making monsters. I also analyze collective and subjective movements of victims refusing to be humiliated. 
In 2012, Colombia had the highest rates of acid attacks in the world, according to the country's newspapers. The perplexity that this situation aroused in me led to my collecting news about this form of aggression and to learn about its high rates of incidence in England, Mexico, India, Bangladesh, Dominican Republic, Pakistan, and the United States. Finally, it led me to begin a more direct survey of the phenomenon in Colombia, beginning in 2019. The data presented in the article below is part of my ongoing ethnographic research into the phenomenon of chemical attacks in that country. Since the first newspaper reports in Colombia came to my attention, I have seen recurring pattern: victims are mostly female, and aggressors are mostly identified as these women's sexual-affective partners or ex-partners. Alternatively, aggressors might be men obsessed with the victims, who have unsuccessfully attempted to woo them or who could not even get close to them in the normal course of events. The news stories also mentioned a specific case in which the attack had been perpetrated by someone unknown to the victim, opening up the possibility that this stranger may have been hired for the attack by an ex-partner or a stalker. The reports indicate that these attacks are mostly forms of gender violence. In other words, the women are attacked because of their womanhood (or perceived lack of proper womanhood) and the attacks are entangled in relationships in which revenge, anger, and retaliation become motivating discourses. Expressions such as machismo, patriarchy and gender violence are omnipresent in these narratives. Looking deeper for information about the attacks, however, I found that they are not, in fact, exclusively directed against women, nor exclusively carried out by men. Some news stories highlight the risks of analyzing the problem exclusively as a sexist act, by mentioning that the number of men who have suffered the same type of aggression is alarming ${ }^{2}$. In these stories, I found nothing about trans people. In the universe of acid attack journalism, as well as in the public policies surrounding it, the world is divided into men and women, and women are emphasized as the primary victims of this sort of aggression.

Before going forward, I want to express that I agree that this type of attack not be encapsulated as something men do to women, or as exclusively gender-based violence. However, my ethnography has so far progressed along gender lines for two main reasons. First of all, the criminalization of these sorts of attacks has largely occurred through public policies that seek to defend women's lives and dignity and which are the consequences of women and feminist struggle. In fact, the visible face of the victim of this crime in Colombia - as elsewhere in the world (Mexico, India, Bangladesh) - has been that of a woman. There is a tiny, almost non-existent, number men in the recovery programs that are run by the Colombian State, even though these programs are open to males. There also have been no stable narratives created regarding this type of violence between or against men. Secondly, the recovery works I've so far been able to uncover has been carried out in and through a network of women engaged in a number of different types of care work. Nevertheless, throughout the text that follows I will try to go beyond gender explanations by investigating and unpacking the nature of the chemical attack itself.
1 Translation by Thaddeus Gregory Blanchette. 2 See, for example: https://www.las2orillas.co/ hay-456-hombres-en-colombia-que-tambien-son-natalia-ponce/ 
In the article below, I bring together 13 in-depth interviews. These include interviews with healthcare workers (two surgeons, a physiotherapist, a psychologist) and a social worker engaged in aiding victims through the recovery process, as well as women who have survived the experience of chemical attack. I also bring in informal conversations with law students who have dedicated themselves to analyzing the Colombian law penalizing this crime. Finally, I include in my results discussions with professionals associated with the Secretariat for Women, a Colombian governmental organization that has organized a working group aimed at combating gender-based violence.

Colombian Law 1639 of 2013 was intended to be a legal resource "through which measures to protect the integrity of victims of crimes with acid are strengthened, added to Article 113 of Law 599 of 2000"3. Before Law 1639, acid attacks were legally understood to be "lesiones personales" (personal damage). Subsequently, the Law Regarding Victims of Acid Attacks was created (Law 1773 of 2016), also known as the Natalia Ponce de León Law. Ponce de León is a woman whose case has been one of the most emblematic in Colombia and the law created in her name led to increasing punishments for acid attacks and their classification as a major crime, eliminating certain benefits for the aggressor, such as the conditional suspension of the execution of their sentence.

I came to this topic in the midst of a broader academic project revolving around humiliation as a category (Díaz-Benítez, 2015, 2019). In the analysis I present below, I interpret attacks with chemical agents as an extreme experience that intends to reveal humiliation in its strongest sense possible, through the creation and exposure of a disfiguration that seeks to morally, symbolically, and psychologically disqualify its victims. I argue that the act of marking and amputating faces leaves the attacked subject alive, but dehumanized, ashamed, and removed from social life. I thus analyze the initial effects of this act in terms of undoing - that is, as an act that affects and changes the relationships and perceptions that the subject has of themselves; as a humiliation that seeks to be ever renewed, stretching through time as a visible scar; as a tool for making monsters.

The article is divided into three parts. In the first, I present the experiences of women who have undergone attacks of this sort, emphasizing the weight gender has in the relationships and situations in which the attacks occur, and in the moral processes they initiate. In the second part of the article, I discuss disfigurement/ amputation as a social and historical practice encompassing a wide range of grammars of excessive violence towards the body. Finally, I end the article describing the rejection of humiliation that the women undertake and which allows them to create the strength and means to reinhabit the world.

\section{The attack, the relationships, and the unforeseen}

When Margarita ${ }^{4}$ arrived at the Simón Bolívar Hospital, she had already spent a week in the Clinica de Ocidente, where she was given first aid and was intubated under sedation, without regaining consciousness. It is common for patients at-
3 See the complete Law in: https://www.funcionpublica. gov.co/eva/gestornormativo/ norma.php?i=53627

\footnotetext{
4 All names used in the article are fictitious except for Natalia Ponce de León, Jonathan Sánchez and Gina Potes, as these cases have been widely discussed in the media and the struggles of both women resulted in the creation of Colombia's laws regarding acid attacks. The names of the health professionals mentioned in the article are also the real names of these people.
} 
tacked with chemical agents to be referred to Simón, not only because the hospital specializes in treating burns, but because some of Colombia's most famous medical personnel work there attending specifically to these types of cases. Dr. José Gaviria is one such person. He has written several articles regarding acid attacks and was crucial in the creation of a protocol for treating these attacks that is now applied throughout Colombia.

It was 2013. Margarita was 19 years old and a parent of a two-year-old daughter with Bernardo, her first and (up to that point) only boyfriend. It was Bernardo who took her to the hospital, gave the first statements and who later needed to notify his in-laws because only a blood relative could refer Margarita to another hospital. “This night is almost endless,” Margarita told me, relating the episode that resulted in acid melting the right side of her face, neck, shoulder, and hand. But Margarita also told me the same thing regarding another fight she had with Bernardo, the root his jealousy, which has been aroused by a flattering comment a friend made to her on Facebook. It was usually nights when Margarita's nightmares became real, after Bernardo came home from the street, disgusted by work and life, often drunk. The couple had lived together for two years - years that ticked by to the rhythm of Bernardo's kicks and punches, delivered to a Margarita who could barely react, let alone defend herself. Bernardo's mother lived nearby and, witnessing her son's pent up wrath, decided to offer help by raising the couple's little girl. Margarita's family had become severely estranged from her after discovering her teenaged pregnancy. With no family ties or money, and with very strong feelings for her husband, Margarita believed that making a home with Bernardo was her only possibility in life. Several times, however, her partner had beaten her into unconsciousness and Margarita often thought, about committing suicide. That's why when "the event" - as she calls the acid attack - she wasn't fully cognizant of reality. In fact, when she recounts the night in question, Margarita claims that she's not sure how many of her memories are real and how many are figments of her imagination. She can remember up to a point, but then there are only flashes. Bernardo told everyone that she had threatened to kill herself by swallowing the acid in question and that he had tried to save her life, but that during the struggle, the contents of the bottle splashed her in the face. This was the version of events that the police, nurses, doctors, and the families received. Moreover, this was the version that Margarita herself first heard and began to repeat to herself and to others. Perhaps this was because she knew it was perfectly feasible; perhaps because she remembered nothing; perhaps because - deep down - she still wanted to trust Bernardo.

It was only two years after the attack that, by chance, Margarita found medical records of her very first appointment. There, she read testimony by Bernardo, assuring authorities that on the night in question, she had suffered psychotic episode, threw herself against the walls until she hurt her head, and threatened to jump of the veranda. Margarita then realized that Bernardo had lied and that, most likely, the story he had recounted of the struggle was also not true. She still believes that it's possible that she threatened to swallow the acid and thinks that, 
if she did, it was probably to convince Bernardo to stop beating her. But it's absolutely clear to Margarita that the blood on her clothes and the walls of her home had been caused by Bernardo's beatings. After all, as she reminded me remember, "this night is almost endless", just as other nights almost never end. The time when Bernardo threw their car in reverse against her inside the garage of the bodega where they both worked, smashing her hands with the rear tire, ceasing his aggression only because a colleague came to Margarita's rescue when he heard her screams.

I met Margarita through Liliana, a woman who was the victim of an acid attack in early 2006. This took place towards the end of that year's Christmas festivities. Liliana was 22 at the time and had come from the neighboring country where she lived to visit her parents and family. One afternoon, while she was walking near her house, two unknown people, one of whom was carrying a pot, threw a liquid in her face and then quickly ran away. As the liquid splashed directly into her eyes, Liliana dropped to the ground, blind and confused, not understanding what had just happened. She was rescued by her parents' neighbors, who notified the rest of the family. Liliana was quickly taken her to the hospital. She felt her skin burning, but she couldn't explain what had happened to her: "Something was thrown at me in the street", she said, attempting to clarify the situation. Liliana was not given immediate care, however, upon her arrival at the emergency ward. Even though she was screaming and crying, there were other situations that were "visibly more serious" due to the fact that they involved blood. These cases were seen to have priority over Liliana's. Reconstructing the facts with the help of her companions, Liliana says that some two hours went by before she was seen by a doctor: "My biggest difficulty was in convincing the [hospital] doorman that I was in serious trouble". Once the doctor finally got around to her, however, Liliana still couldn't explain what had happened.

The chemical, she explains, doesn't attack the skin at first: it works from the inside out. A situation like this is thus a race against time. With each passing second, possibilities fade away. By the time the doctor saw her, Liliana's bones had already been dissolved, as well as most of her facial muscles. Her skin had a green tinge and was already starting to peel off. Her eyelids had melted shut and her nose and right cheek had sloughed off. 14 years later, Liliana told me that she still doesn't know why she had been attacked. She was a person who had no enemies: why would anyone want to disfigure her?

Why did this happen? Who did it? These were also the questions that Natalia had. Unlike Liliana (who to this day knows nothing about her attackers), the voice of Natalia's attacker reminded her of a fight she had had another resident of her neighborhood that had taken place while Natalia had been taking her dogs for a walk. This episode, which took place around 10 years before the attack, apparently aroused a desire for revenge that led to the attack, which took place in March 2014. It was Natalia's recognition of the voice of her attacker that resulted in the identification and arrest of a man named Jonathan. This case received enormous media attention in Colombia, mobilizing authorities from many different institu- 
tions, from the several different police forces and the judiciary, to the Presidency of the Republic, President Juan Manuel Santos offered a reward of 75 million pesos for anyone coming forward with information about the Natalia's attacker. After the attack, many different versions of it were offered up. Testimony from people who knew the aggressor; health experts; lawyers; journalists... even the victim's family began to dispute the "truth" regarding the motivation for the attack. One young man said he had met Jonathan at a drug rehabilitation center, where he had been hospitalized for four months due to heroin use. This man claims that in spite of Jonathan's addiction, he seemed to be an absolutely normal person who certainly was competent to stand trial. Another man reportedly met Jonathan at a nursing home for people with depression, where he learned that Natalia's attacker had been diagnosed with schizophrenia. There, Jonathan had talked about the voices he heard, which gave him messages that caused him much anguish. Both statements agree in their claims that Natalia's attacker led a solitary life, had problems with socialization, very much wanted a girlfriend, and suffered from anxiety in a way that made people uncomfortable to spend much time with him. This mental illness narrative of was employed by the Jonathan's defense team's forensic doctor during his trial by jury. Jonathan, it was claimed, suffered from paranoid schizophrenia and, in his hallucinations, he saw Natalia as a being representing hostile emotions. The prosecution's attorneys believed that the mental illness narrative was a ploy to garnish sympathy with the public and the jury, so that Jonathan would not receive a criminal sentence but, instead, a mandatory detention in a psychiatric ward. Schizophrenia, the accusation insisted, does not necessarily make the subject lose consciousness of his actions, nor does it distance him from reality. Natalia's family members said that after the conflict with the dogs, Jonathan continued to harass her, even writing insulting graffiti about her on the walls of the neighborhood where they both lived. The media spread the idea that the boy had been wanting to carry out the attack for 10 years, hypothesizing that his obsession was based on his unresolved erotic-affective interest in Natalia.

In front of the jury, Jonathan confessed that he thought of committing murder and that he had wished to obtain a firearm for this purpose. He changed his mind, however, and bought the chemical he would use on Natalia a few months before the attack. It was thus established that Jonathan had planned the attack. On the day he assaulted Natalia, he presented himself at the building where the woman's mother lived (whom she visited daily), identifying himself to the doorman as Bernardo Londoño, the victim's ex-boyfriend, and asking for Natalia to come down and meet him or authorize his entry into the building. Several cameras captured images of Jonathan walking from his house, carrying the container with the acid in his hands. His cold attitude at the time of his arrest led the jury to conclude that not only was Jonathan fully aware of his acts, he took care in planning how the attack was to be carried out. Jonathan received a 21-year and 10-day sentence for attempted aggravated homicide.

When Jonathan threw the chemical directly in Natalia's face, she fell to the ground. The camera images show him leaning over the body, spreading the liquid 
over her and then quickly running away. Natalia tells of how she felt an unbearable burning sensation and suffered an immediate loss of vision. She felt her clothes fall apart and patches of her skin melting. Helped by the doorman, her mother, and by neighbors, Natalia took a shower in order to remove the liquid from her body and left for the hospital, getting stuck in a long traffic jam en route. What followed was a long recovery that began with reconstruction surgeries, grafts, therapy to restore functional capacity, and prolonged dosing with morphine. Some side effects also occurred during this period, such as the loss of mobility in one of Natalia's hands due to nerve blockage.

The experiences of Liliana and Natalia are similar in terms of unpredictability of the attacks they suffered. Here, the unforeseen and the random conjoin, creating an aura of destiny that is very specific to these experiences. Alicia's case was very different. She was attacked by her sexual-affective partner at home while she was carrying her baby in her arms. Rita's experience was also different. Her husband and father of her children assaulted her when she finally mustered the strength to throw him out of the house after many years of violence. Or take the case of Claudia, who was doused with gasoline and set alight by husband - her attacker finally extinguishing the flames when he judged that she had been damaged enough.

According to the German sociologist Wolfgang Sofsky (2006), every massacre is the same, is identical in nature. What this author is pointing out is that, regardless of the reasons that generate this excessive violence, the behavior of murderers in a massacre is always the same. There is thus a "uniformity to massacres, which are not related to objectives, but to the very dynamics in which they develop which are universal" (Ibid., p. 159, my translation). Analyzing the narratives I collected with an eye to the moments in which the attacks took place, I agree with Sofsky. The behavior of the attackers is identical: their methods of execution, their assault on the victim's body, and their subsequent escapes. Even when they remain with the women they have attacked, they deny their acts or create mechanisms to silence victims regarding their accountability. However, the meanings that women give to the attacks vary widely, depending on the relationship they had with the perpetrator, the circumstances in which the attack took place, and the subsequent acts that took place during the more-or-less effective processes of recovery the which, in turn, determined their possibilities for rebuilding their lives. For Margarita, Alicia, Claudia and Rita, the attack is an apex of a trajectory of aggressions that they had already been experiencing in their relationships. For Liliana and Natalia, the attack is interpreted as a random, almost karmic turn of fate. A doom, in the old English sense of the word.

I thus believe that it's important to distinguish between acid attacks. There are those that can be seen as is a critical event that creates a before and after, unpredictably turning the world upside down and opening up questions of luck and destiny ("Why me?") - frighteningly fortuitous and impossible to imagine even in one's worst of nightmares. Then there are those attacks that are monstrous, cold, horrific, but by no means an unexpected event. The acid attack suffered 
by Margarita was the most radical attack she had experienced at the hands of her abusive partner and the one that caused the most consequences. Even so, it can be seen as a point in a continuum of increasing aggression against her body. Bernardo was her husband, the father of her daughter; Margarita's world at a time when her family network was enormously fragile. He conducted the attack during a tragically routine brawl that got out of hand. Maybe that's why Margarita believed, or wanted to believe, the story Bernardo told, as this was reasonable within the relationship's already established repertoire. Maybe that's why, upon leaving the hospital and telling herself that Bernardo would always be the father of her daughter, Margarita went back to live with him.

I don't know the minute details of Claudia's matrimonial history, not in the least because, in our conversations, she always preferred to focus on the story of her recovery. But I learned from the doctor and social worker who accompanied her after the attack that her husband was always present at each appointment and therapy session, rushing to answer the questions that they asked Claudia and constantly showing himself deeply saddened and concerned about the "accident" that his wife had suffered. It took a long time for Claudia to "confess" (in a context of psychological care) to the true circumstances behind her disfigurement.

The unforeseen attack creates a faceless enemy and a constant sense of dread. Liliana is still afraid, when walking through the streets, if someone approaches her with a bottle or a glass in her hands. In fact, any object that someone might be carrying and that she cannot identify scares her to the point she sometimes becomes paralyzed with fear or changes sidewalks. Liliana tells me that, in her dreams, she sees the outlines of her attackers, but can never identify them She says she always feels her tormentors are close and know everything about her life.

Threats are present in both contexts. In those cases where the aggressor is unknown, there is the threat that they will continue their attacks, on the victim or on members of the victim's family. The threat takes on other tones in the narratives of the women who suffered attacks by partners or ex-partners. "If you're not mine, you won't be anyone else's"; "You will remember me"; "Every time you see yourself, remember what you did to me"; or "You'll see what happens if you leave me" are declarations that exist in these cases as harbingers. They offer up indications that the aggressor's intent is not to kill, but to leave a permanent and visible mark on the victim - a mark that prolongs the effect of relationship in time. Furthermore (and this is the most common analysis presented in the media, by feminist readings, and among public policymakers), by attacking beauty and disfiguring it, the aggressor seeks to eliminate any possibility that the victim can to establish affective and sexual relationships with new partners. This perception of the attack is also common among women who associate this type of attack and threats they have been subject to with possessive behavior, constant jealousy, and acts that reiterate their male aggressors' desire for women to remain indoors and in charge of the home. If we follow this interpretive path, we can understand the acid attack as denoting a desire for possession that takes place within broader relational dynamics of the victim's abasement and separation from the world and from 
herself. To possess a person implies encouraging feelings of self-dispossession in the "possessed" subject: it implies impacting their subjectivity to the point of making them believe that they do not belong to themselves. Elsewhere, (Díaz-Benítez, 2015) I have associated the desire for possession with humiliation. Analyzing representations of extreme humiliation fetishes, I have claimed that such acts were made possible by a hierarchical relational organization, in which a person or group boasts of power, dominance, and ownership over another. When it comes to affective relationships, we know that acts of possession and domination do not necessarily happen through the exercise of vertical power over another, but through tense relational grammars in which aggression, violence, and humiliation exist as modes of negotiation and communication, blurring the boundaries of abuse and consent (Gregori, 1993; Díaz-Benítez, 2019; Fernandes et al, 2020). We also know that there are life experiences among couples in which, in the name of love, subjects joyfully engage in situations of submission and self-abasement. Among many other reasons, this may occur either because the members of these couples see this position as a kind of virtue through which they find feelings of fulfillment; because they believe it makes a positive statement related to ideas about sacrifice and family; because they encounter a certain emotional well-being while living situations of obedience; or because there is a pleasurable introversion of hierarchy.

Even in these circumstances, however, the experience of possessing another or of belonging to another, implies a stripping of the will. And in affective repertoires, this act is often guided by sociocultural gender scripts that demarcate divisions between bodies which have power and bodies over which power is exercised. Loss of self-control, inability to make decisions, little or no self-esteem are things that frequently appear in women's narratives describing the affective relationships characterized by experiences of aggression and humiliation and in talking about their attitudes towards life right after am attack. I see here a thread that unites emotions and experiences before and after the critical event delineated by circumstances of abasement. Before, because the humiliation experienced at home causes, in many victims, moral and emotional debilitation. After, because the aggressions against the body and disfigurement of the face of the victim provoke, in her, feelings of shame and humiliation in interpersonal interactions, especially in public areas. In both instances, offenses, threats, and humiliation have the ability to change the social status of the victims of the attacks.

When I started to gather news stories about attacks with chemical agents, the word "humiliation" caught my attention. It kept popping up in the narratives: "People pointed me out in the street, men humiliated me. I thought no one would ever love me," said Katie Piper, a British T.V. host who was burned by her ex-boyfriend. ${ }^{5}$ Among the women I met, (including those who did not have very visible scars or who had so far undergone successful surgical procedures), they went through long periods in which they felt unable to move after the attack, in which they felt that the psychological consequences of their relationships and the attack were too deep. Before and after the attack, they faced "words that incapacitate",
5 https://extra.globo.com/ mulher/apresentadora-queimada-com-acido-por-ex-namorado-comemora-maternidade-lanca-novo-livro-13634202.html 
as Rita expressed it: "You are useless without me and worth even less as you are now", "Look at yourself! What man will want you?" were two of the things she heard from her ex-husband.

Threats, insults, and offenses are part of a range of forms of enunciation that operate effectively because of humiliation. Inspired by J.L Austin and his theory of performative acts (1962), much has been written about insult and injury in contexts of contempt for gender and sexuality (Haritaworn, 2010; Almeida, 2015). Regarding this Didier Eribon (2008, p. 29), says that "Injury produces profound effects on an individual's conscience because of what it says to him: 'I assimilate you...,' 'I reduce you to...”.' Fanon (2018), among several other authors, has talked about the psychic effects of racial offense. Althuser's (1985) ideas about interpellation have also given rise to ways to analyze subjectivities which, in the case of Judith Butler, have been developed in terms of recognition (2004a). In Language, Power and Identity, Butler (2004b) considers injury as a linguistic act that has perlocutionary force (that is, causes effects on the recipient of the message) depending on the words and modes of elocution employed. If these not only say, but do, they are reconfigured through time into ritualized repetitions, according to Austin. An offense thus materializes as action at the moment it is enunciated; it simultaneously extrapolates this moment by evoking a past and a future in which it is reiterated.

What I am interested in highlighting here is the psychic and subjective work of humiliation, or what humiliation as abasement is capable of doing to the subject when subjected to logics of repetition that result in introjections of inferiority. Through this, it becomes possible to extract some intelligibility regarding why women continue in relationships with their attackers, even after the attack and through repetitive cycles of violence in some cases. As a woman I talked to in the course of another research project told me, "I really believed that I was nobody and that I had nowhere to go".

\section{On making monsters}

What we call "monsters" has changed throughout history. Since Antiquity, these misshapen and hybrid figures (which often mix human, animal, vegetable, demonic, and even mineral characteristics) have inhabited social imaginaries as objects of repulsion and fascination. They also provoke laughter because they are simultaneously associated with ridicule, fear, and terror even as their bodies were understood particularly from the Middle Ages on (Kapler, 2004; Leite Jr, 2012) to be the work of the Devil or other malign entities. In the 18th century "monstrosity" began to be understood in more naturalistic terms, with monsters being increasingly cast as biological anomalies evidencing natural disorder. The bodies of hermaphrodites and Siamese twins were slotted into this category. As Foucault has shown (2001), from the 19th century on "behavioral monstrosity" became the dominant discourse regarding the whys and wherefores of monsters, and psychiatric and legal power would operate upon this sort of imagined disorder. Throughout this process, however, the linkages between biology and monstrosity have never 
been completely erased, as was clearly seen in the $19^{\text {th }}$ century in the proliferation of freaks (such as the emblematic case of Joseph Merrick, better known as the Elephant Man), and freak shows. These are best understood as "human zoos" that claimed to organize knowledge and expertise regarding human diversity through the combination of such "scientific" notions as race, gender, savagery, disease and degeneration. Even today, monstrosity exists in anatomy textbooks as a category that related to bodies and life possibilities 6 .

Monsters live on the edge ${ }^{7}$. Attitudes such as curiosity, disgust, laughter, repulsion, or pity have been culturally and historically legitimized with regards to them. These reactions create and simultaneously reproduce the monstrosity they reject. Monsters have historically challenged the limits of humanity.

I understand the acid attack to be a way of making monsters. That is, it is an action that aims to remove the attacked subject from the plane of normality, delegating to them the social space of the deformed, the strange, the pathological. Monstrosity may seem like a strange or even pessimistic category with which to refer to people who have suffered involuntary, untimely, and cruel attacks against their bodies. What I want to argue, however, is that if society has always created monsters, we can think of technologies of violence such as amputation and disfigurement as acts geared to create this very type of subject. The acid attack seeks to make a monster. With regards to the victim, it does not seek to attack life, but the very quality of life; to eliminate the possibility of a good life. Its purpose is to undo without the undoing itself being total; to diminish the victim's being without causing their physical death. It seeks to emotionally waste and to morally undermine. Like monsters, those who have been attacked with acid face isolation, loneliness, and reluctance: the intent of the attack is to push them to the edges and shadows of the social world.

If it is true that we do not doubt the humanity of those whose faces were altered through the violence of acid attacks, it is also true that we have compassion for them - a feeling that stipulates a hierarchical form of interpersonal positioning (Fassin, 2012). The observer's curiosity or repulsion in the face of disfigured faces may be experienced by the victim as humiliating. This is because this gaze is not sustained: it timidly deviates, whether the reason for this is discomfort or even if it is respect.

Shame is a common response in experiences. Shame to go out, to be seen, to have to answer thoughtless questions. The women I met often distanced themselves from the world as a result of this shame and this, in turn, often led them to lose their economic autonomy or the income they contributed to supporting their family. This led them to feel impotent. They came to depend on their closer relationships and some of the women, such as Liliana, sold their homes in order to pay for their surgeries. These other losses, in addition to the physical pain caused by the attacks, contributed to foster feelings of destitution and prolonging the sense of loss of self among attack victims. Shame is the public phase of humiliation, as Martha Nussbaum (2006) has said. In the experiences of the women I met, shame takes on broader contours: the acid attack was directed against the victim's face -
6 For example, see Gabriela Placoná Diniz's (Departamento de Anatomia do Instituto de Ciências Biomédicas da Universidade de São Paulo). Beyond normality, there are anatomical variations, which are organic differences from the normal that do not hamper an individual's functions. Then there are anomalies, which are morphological alterations that differ from the biological norm and which do negatively affect an individual and their life chances. Finally, there is monstrosity, in which biological deviations from the normal deform the social construction of the body and negatively affect the individual's physical functions and which are incompatible with life.

7 "[...] on the edge of knowledge, the edge of the human, the edge of the known and socially recognized Earth (islands, the depths of the sea, foreign and exotic lands, "ghettos", "peripheries"). But perhaps the most import thing here is that the monster lives at the limits - on the edge - of the established categories" (Leite Jr, 2012, p. 562). 
the basis for human (re)presentation in the world and thus for the construction of subjectivity - and, in doing so, weakened other functional capabilities.

"It's like being kidnapped by life", Rita told me. "I felt trapped in my own body. I felt that I was worthless". Expressions such as these seem to accompany Jack Katz's observations (2013, p. 235) when he says that the humiliated feel so diminished that they perceive the whole world as if it were looking down on them. Humiliation is a holistic feeling, says Katz. It threatens to engulf the person with a deep understanding that they do not control their own soul. Humiliation, says Avishai Margalit (1998), reveals a person as sub-human, or as an incomplete human; as if they lacked important parts or aspects of what makes them human in a broader sense. For those who literally lose their face and move away from public life, humiliation becomes an extreme experience of undoing - a state of being or a prolonged social state that impacts their life trajectory and relationships.

What else can the act of burning bodies and faces tell us, beyond pointing to the failure of affective relationships and modes of interaction that are crosscut by gender? When I try to answer this question, I quickly remember how mutilation - of living or dead bodies - has long been a part of the repertoire of violence in Colombia's sociopolitical history. I also recall the various torture techniques that Latin Americans have heard about in some detail, being that we live in a region that has witnessed several dictatorships. I remember Roger Casement's descriptions of the Congo and of Putumayo. I remember the descriptions of genocide in Rwanda. I remember the Muslim, the body to be wasted that reminded those who survived the German holocaust of the state they sought to achieve (Agamben, 2000). I remember the elimination techniques used by paramilitary and drug-trafficking armies across the world; of the technologies of punishment employed during chattel slavery. Finally, I remember how the torture of and cruelty towards bodies are threads that tie the history of humanity together. Acid attacks seem to be part of this larger grammar of the right to maim (Puar, 2017). Like massacres, they theatricalize excess (Blair, 2005). Implicit in them is the desire for penetration, which may indicate a desire for conquest, possession, abasement, or a pleasure for pain itself - for the suffering of the flesh. I believe (as I have said elsewhere regarding extreme humiliation fetishes (Díaz-Benítez, 2015, p. 85) that the person who performs this act or the person who enjoys it does not necessarily see gendered bodies, nor even bodies in their entirety: instead, they perceive fragments (extremities, faces, head, genitals). Violability is thus also related to fragmentation. Perhaps this answer, in part, the question that anthropologist Maria Victoria Uribe (1998, p. 8) asked in her research on massacres in Colombia: "How can you explain the recurrence of such practices as tearing bodies apart with a chainsaw?".

Penetration evokes the pleasure of intimacy. I agree with Sofsky (2006) when he contradicts ideas regarding the necessary dehumanization and distancing of the Other as a precondition of atrociously attacking the Other. Excess seeks proximity. As Elsa Blair (2004, p. 169) remarks about mutilation, "the assassin works by hand and up close". The very act of attacking with acids - that is, aggressively employing a substance that penetrates and appropriates the body - perpetuates 
an intimacy that trespasses being in its subjectivity, leaving the attacked frightened, depressed, monstered, humiliated. There is a very intimate aspect of this humiliation: acids, like torture, aim to prolong agony, to stop time. In the words of Michael Taussig, following Nietzsche:

As a form of cosmic surgery, bodily mutilation has its own aesthetic ensuring that memory will be everlasting, as Nietzsche tells us in The Genealogy of Morality. "When man decided he had to make a memory," he writes, "it never happened without blood, torments and sacrifices (the sacrifice of the first born belongs here), the most disgusting mutilations (for example, castration) ... all this has its origin in that particular instinct which discovered that pain is the most powerful aid to mnemonics" (2014, p. 97).

There are attacks that seem to consider a body to be "too human". In an interview with the newspaper Las2Orillas, Gina Potes (considered to be the first woman attacked with acid in Colombia) comments on the timing of the event. There is a knock at her door and a woman catches her attention, asking her for an address. This is a distraction that allows a man to quickly throw liquid in her face and exclaim "Who told you to be so beautiful?". ${ }^{8}$ For reasons of space, I cannot dwell here on retaliation between women or on other possible ways of interpreting gender relations in addition to those mentioned throughout the text. But I bring up Potes' experience to draw attention, once again, to the urgent need of expanding our analysis of this type of aggression by insisting on its foundations: it is an act of mutilation directed specifically against beauty. "The face is my identity", "the face is unique", "attacking beauty is taking away the place it occupies in society, it takes away the possibility of existing”, "I will never be beautiful again": these were all expressions that I heard during the course of my field work in the voices of the female survivors of acid attacks and the professionals who help care for them. ${ }^{9}$

Finally, I want to say that this specific type of attack, like so many other forms of exacerbated violence, has the ability to make a monster twice over. If we think of the aggressors, we quickly arrive at the conclusion that any moral reaction to them that goes beyond contempt seems almost unintelligible. Diving into Jonathan's experience, for example, and the claims regarding his possible mental deterioration, can open doors to ways of understanding or justifying the attack which would produce feelings of pity and possible legal effects. But empathizing with Jonathan's probable mental illness creates a moral impasse in us: in the end, mad or not, his attack evokes evil in its rawest form. Hence, routinely, full of, disgust, we call serial killers, pedophiles, torturers, abusive military police and all those who abuse the bodies of others as monsters - and yet their acts are absolutely human, as Sofsky points out.

\section{Refusing humiliation}

The ethnographic path I took through such institutions as the Natalia Ponce
8 Available at: https://www. las2orillas.co/gina-potes-la-primera-mujer-agredida-con-acido-en-colombia-transforma-sus-cicatrices-en-arte/

9 Regarding the face and uniqueness, see Lévinas (1980). 
de León Foundation and the Secretariat for Women an organ of the Bogota Administrative District, led me to the work of these and other female support networks, such as the Reconstruyendo Rostros (Reconstructing Faces) Foundation and Renacer (Reborn). These were created by and brought together women who had lived through similar types of attacks in different places Colombia. The networks mobilized aid for these women in the public and private sectors, creating psychosocial development workshops, work insertion actions and follow-up applications of Laws 1773 and 1639. My journey led me to talk with women who have been participating for many years in one or more of these networks, through which many of them began their long road through surgery and recovery. It was in these spaces that many of the women claimed the began processes of self-esteem recovery and emotional strengthening in order to face life after the attack. Notions such as empowerment and the reiteration of categories such as machismo and patriarchy are combined in these women's discourses and the pedagogical processes they engage in are full of narratives about the need for rebirth through forgiveness and resilience. It is because resilience has such weight in the life trajectories I have encountered that I allow myself to interpret its construction as the opposite of humiliation. It is the leap of faith that enables these women to struggle to gradually abandon feelings of inferiority and their silence in and remoteness from the world. Faced with the act of making monsters implicit in the disfiguring attack, "survivors" or "the resilient" have responded with slow and uncertain efforts to cure themselves.

When Margarita was attacked in 2013, a medical routine had already been established for patients who had been burned by chemical agents. Upon arriving at the hospital, Margarita's clothes were removed, her body was washed, and her skin received first aid. Over the following days, she underwent her first surgeries. Over the months she was hospitalized, Margarita underwent daily physical therapy. She received massages prevented her eye from permanently closing and the right side of her mouth from continuing to droop. She was given the necessary blockers, filters and creams, latex masks, acrylic masks, and the splints that she was supposed to put on her face. She learned to make expressions that would gradually loosen the skin and stretch her scars. Margarita met Yinna at the hospital: the professional who oversaw this part of the recovery process.

Through these processes, Margarita's face recovered through time and dedication. This was also possible because the type of chemical that hit her is one of the least aggressive, even though it is still highly dangerous. Despite these best practices, however, something was very wrong. Margarita couldn't speak and swallowing became painful for her. The time she spent intubated and this caused a lesion in her trachea. This led her to new and successive hospitalizations in clinics where care was extremely precarious. This was a huge problem. Margarita says that for weeks, she was on dexamethasone and corticoids and this in turn gave her Cushing's syndrome. Diagnosed with tracheal stenosis and a deep lesion in her respiratory duct, Margarita was unable to walk, move, or do anything without being overcome by fatigue. Once again, she became completely dependent on 
Bernardo. Because of these problems, she became closer to her family, and with their support, little by little, Margarita separated from her husband and finally decided to press charges against him.

The reconstruction of Margarita's body required two surgeries on her cheek, mouth, and neck; six on her right eyelid; and ten on her trachea. The surgeries on the scars on her arm and hand would come later and, seven years after the attack, Margarita was still waiting on these. Despite the notable improvements in her face and breathing, Margarita is of the opinion that she only "came back to life" in 2018, when she was able to regain custody of her daughter and met the group of women with whom, as she said, she "empowered herself". It was Yinna, the physiotherapist, who referred Margarita to the group, telling her about the work done by the Secretariat for Women. Yinna contacted Clara, a beautician who offered free eyebrow micropigmentation for burnt women. Yinna also introduced Margarita to Ivana and her husband, two tattoo artists who also work on chemical scars (or the scars left by the grafts from treating these) for free. In this circuit, Margarita met Diana, a dancer who offered dance as a form of therapy and rediscovery of the body. It was in these workshops that Margarita received psychological attention and met women with stories similar to hers. As she says, "I understood that I couldn't let any man treat me like that".

This is the most successful story I've encountered in my fieldwork so far, and Margarita's story allows me to talk about recreating life and denying monstrosity in a more-or-less typical relational plot at a time when public policies regarding medical and psychosocial care have increased in effectiveness. But the struggles of these women are haunted by the stories of the many who have failed to recover and who have succumbed to pain, taking their own lives or refusing to step out of the shadows. "Not accepting the loss of one's face" triggers long processes of depression, fear, and the introjection of monstrosity into one's life. As Rita told me, "my fight is with the mirror. I spent years without being able to look at myself".

Rita, like Liliana, was attacked at a time when nothing was known about acid attacks. Liliana suffered severe wounds and, even after 14 years, more than 45 surgeries, and around 190 procedures, her face still needs more work. To replace the lost skin on the face, skin grafts were taken from other parts of her body: her buttocks, back, and legs. "My whole body has scars, although the acid just fell on my face," Rita told me.

They removed very thick layers of skin from me. Nowadays it's not like that. I should have used an expander on my face and they should not have taken off this thick layer of skin from my leg. Me and the women who were attacked before the protocols were established were guinea pigs [...] The word "grafts" is very difficult, very painful for me. In my case, the struggle has been to recover functions. It's not even about looking beautiful, because my chin was melted down to my neck and I couldn't move it. My eyes were closed. I've had 10 eyelid surgeries and I've been able to improve my vision. The acid affected my eye lens and, even though I used medication 
for it, I need a surgery that can only be done when I have recovered all of my eyelids. When I started the surgeries, they told me that the process would be long: at least 20 years. I'm already fourteen years in and it's still going on.

Saving the patient's life and restoring their functionality and autonomy were the priorities for the medical practitioners who treated victims at the time. Not a few attack victims faced obstacles from health practitioners because, before the protocols and care routines that gave rise to the Colombia's laws regarding these sort of attacks, the procedures necessary for recovery were not funded by the State. This was largely because these procedures were understood to be aesthetic in nature. "What is aesthetic about wanting to have a nose to breathe through, an ear to hear with, to move your neck?" asks Liliana.

But for some women who were attacked before these protocols, being able to see, breathe, eat, or walk did not eliminate monstrosity. For these women, the resumption of their lives could only be complete with the recovery of their faces. They don't believe that they will regain their original countenance, but they want one that they can look upon in the mirror and take into the street without becoming the target of sly looks, gossip, or spiteful and humiliating comments.

Fernanda, another of the women I met, was so obsessed with taking care of her face that she was completely dedicated to applying creams, performing massages, and practicing grimaces. She became so dedicated to recovering her face that she neglected to care for her hand (also hit by the acid) to the point where her fingers became stuck together. Daniela, who had been accidentally burned by combustible agents, recognized her "monstrousness" when she had sex with her husband for the first time after the experience and, throughout the act, he didn't open his eyes. Ana, a lady who suffered an attack by her husband more than 30 years ago, was forced to continue her life without any time to rehash events. Poor, a fruit seller in a public square near her home in the interior of Colombia, the acid her husband used melted the skin on Ana's face, melting it to the skin of her shoulder. From that moment on, Ana lost the ability to fully move her head. Even with her functionality severely impaired, however, she had to continue to struggle on as she had done before: in the end, she needed to support herself and her children.

Ana's case makes me think that refusing monstrosity can also be a process not of face reconstruction or the recovery of function, nor of refusing to be gawked at or pitied, but of accepting light and everyday life as one knows it. It is probable that the presence of the same disfigured woman, day after day selling fruit in the same square and at the same time, would eventually become no longer be strange to those who see her. Her presence becomes routine. Perhaps familiarity can undo monstrosity.

I began to believe this because, after hours of talking to women, I found I could no longer see their scarred faces. This happened to me most deeply with Liliana. I found myself penetrated by her words and invaded by the strength she conveyed when narrating her struggle for life. Liliana is the leader of the network formed around the workshops offered by the Secretariat for Women. She gave me a beau- 
tiful speech about the need to work on pain, frustration, and anger. She tells other women that sometimes the psychological scars are worse than the physical ones and that it takes some sort of "click" to push one to action. Liliana and Mariana, the psychologist, insist upon the need to forgive. "Forgive who?" I asked Liliana. "Forgiveness is accepting life, one's condition, and the fact that it is not possible to change things $100 \%$," said Liliana. "Only then is it possible to begin again".

Choosing life requires refusing humiliation by transforming one's emotions, their intensity, or their direction. For resilient women, anger at their aggressors does not necessarily stop being anger. It no longer paralyzes these women, however: it must become impetus for action. Upon who, exactly, is forgiveness bestowed? That's not as clear. There are many women who feel guilty over what happened to them, for having remained in relationships in which they endured different types of aggression for years. In these cases, therapists insist that forgiveness, above all, must be directed by the women towards themselves. Guilt, like humiliation and fear, is a feeling that pulls one down and denies the possibility of recovery. It is also true that many women try to forgive the unforgivable, either because they religious narratives push them to unconditional forgiveness, or because there is, in their past, an affective history that unites them with their aggressors (who are often the parents of their children). But whether these women know their attacker or not, retaining their hatred and contempt for their aggressor is too much weight for these women's souls. I believe that what these women call forgiveness closely approximates what Rangel (2020) calls fractured reconciliation in his research on families dealing with a rapist in the home. This is "forms of life that emerge when relational fractures exist, but are mended, twisted, and then sewn back together" (Ibid, p. 2). Forgiveness is also an abstraction that can be directed at life, destiny, and the past.

Going forward with one's life is something that "needs forgiveness, self-esteem, and resilience". "It is necessary to resume family relationships, to collectivize the malaise in order to understand that one is not alone", insists Liliana. She told me that it took her nearly a decade to understand that she is not a victim but a survivor, and that she prefers to think of herself as resilient.

The notion of the victim is important, because it denotes that there was a violation of rights and that it is necessary to take action to restore life. We were all victims of a crime and the State has to respond with policies that help us. But victim cannot become an identity or a form of existence. We now propose the word "resilient", by which we mean that we are not just surviving violence, nor are we merely existing: we are transforming our lives, adapting to new conditions and organizing new life projects. Being resilient means taking what happened to us and using it as a platform.

Resilience, in these narratives, is situated as a performative and heroic utterance, simultaneously feminist and existential. This category, Gutterres explains (2020), is common in approaches to public policy, human geography, and psy- 
chology, and it centers on processes of resistance. But the meaning of the term as it has been adapted to the psychological field, as Liliana employs it, recovers the meanings attributed to the term in the realm of physical chemistry. Here, resilience is seen as "returning to an original shape after being subjected to elastic deformation [...] [it denotes] a characteristic of some materials that have been deformed after being subjected to heat sources, but which were nevertheless able to revert to their original form when removed from the heat" (Ibid., p. 104).

There is no promise of a return to original form for people who have been attacked with chemical agents. Resilience is the acceptance of life's ills, even when they are traumatic or precisely because they are traumatic. It is the act of morally reorganizing oneself, building strength to reject monstrosity and imagine a future. “Can't you see that darkness shows you the stars?", as Liliana asks. Moved by this metaphor, I tell her: "if I ever write about you, that's what the book will be called". "No"." Liliana replies. "It's better to call it 'Kintsugi". I had to take my cell phone and quickly access google to know that this Japanese word means: "the value and beauty of scars". It is an art that consists of repairing a broken ceramic items by gluing the pieces together with gold, silver, or platinum dust.

Liliana tattooed kintsugi on the scar on her leg from which most grafts were taken. The concept has inspired her to lead several women to paint flowers and colorful shapes over their injured skin. For these women, this gesture creates another relationship with their bodies, gradually opening space for new possibilities of reconciliation with themselves and with the outside world that, after the attack, they insisted on not inhabiting. 


\section{References}

AGAMBEN, Giorgio. Lo que queda de Auschwitz. Homo sacer III. El archivo y el testigo. Madrid: Pretextos, 2000.

ALMEIDA, Daniel Mazzaro Villar de. O poder da palavra e o insulto de gênero. EID\&A Revista Eletrônica de Estudos Integrados em Discurso e Argumentação, llhéus, n. 8, p. 80-97, jun. 2015.

ALTHUSSER, Louis. Aparelhos ideológicos de estado: nota sobre os aparelhos ideológicos de estado. Rio de Janeiro: Graal, 1985.

AUSTIN, John Langshaw. How to do things with words. Oxford: Oxford University Press, 1962.

BLAIR, Elsa. Mucha sangre y poco sentido: la masacre. Por un análisis antropológico de la violencia. Boletín de Antropología Universidad de Antioquia, Medellín, v. 18, n. 35, p. 165-184, 2004.

BLAIR, Elsa. Muertes Violentas. La teatralización del exceso. Medellín: Iner; Universidad Nacional de Antioquia, 2005.

BUTLER, Judith. Vida precaria. El poder del duelo y la violencia. Buenos Aires: Paidós, 2004a.

BUTLER, Judith. Lenguaje, poder e identidad. Madrid: Síntesis, 2004b.

DÍAZ-BENÍTEZ, María Elvira. O espetáculo da humilhação, fissuras e limites da sexualidade. Mana, v. 21, n. 1, p. 65-90, 2015.

DÍAZ-BENÍTEZ, María Elvira. O gênero da humilhação. Afetos, relações e complexos emocionais. Horizontes antropológicos, v. 25, n. 54, p. 51-78, 2019.

ERIBON, Didier. Reflexões sobre a questão gay. Rio de Janeiro: Companhia de Freud, 2008.

FANON, Franz. Pele negra, máscaras brancas. Salvador: EDUFBA, 2018.

FASSIN, Didier. Humanitarian reason: a moral history of the present. Berkeley: University of California Press, 2012.

FERNANDES, Camila; RANGEL, Everton; DÍAZ-BENÍTEZ, Maria Elvira; ZAMPIROLI, Oswaldo. As porosidades do consentimento. Pensando afetos e relações de intimidade. Sexualidad, salud y sociedade, Rio de Janeiro, n. 35, p. 165-193, 2020.

FOUCAULT, Michel. Os anormais. São Paulo: Martins Fontes, 2001.

GREGORI, Maria Filomena. Cenas e queixas: um estudo sobre mulheres, relações violentas e a prática feminista. São Paulo: Anpocs; Paz e Terra, 1993.

GUTTERRES, Anelise. As diferentes formas de resistir em um contexto de ameaça de remoção de moradias. Ayé - Revista de Antropologia, v. 2, n. 1, p. 100-121, 2020.

HARITAWORN, Jin. Queer injuries: the racial politics of "Homophobic Hate Crime" in Germany. Social Justice, v. 37, n. 1, p. 69-87, 2010/2011.

KAPPLER, Claude. Monstros, demônios e encantamentos no fim da Idade Média. São Paulo: Martins Fontes, 1994.

KATZ, Jack. Massacre justo. In: COELHO, Maria Claudia (Org.). Estudos sobre interação: textos escolhidos. Rio de Janeiro: EdUERJ, 2013. p. 211-284.

LEITE JR., Jorge. Transitar para onde? Monstruosidade, (des)patologização, (in)segurança social e identidades transgêneras. Estudos Feministas, Florianópolis, v. 20, n. 
2, p. 559-568, maio-ago. 2012.

LÉVINAS, Emmanuel. Totalidade e infinito: ensaio sobre a exterioridade. Lisboa: Edições 70, 1980.

MARGALIT, Avishai. The decent society. Cambridge: Harvard University Press, 1998.

NUSSBAUM, Martha. El ocultamiento de lo humano. Repugnancia, vergüenza y ley. Buenos Aires: Katz, 2006.

PUAR, Jasbir. The right to maim: debility, capacity, disability. Durham: Duke University Press, 2017.

RANGEL, Everton. Conciliação fraturada. Quando o estuprador está dentro de casa. Mana, Rio de Janeiro, v. 26, n. 3, e263204, 2020. Disponível em: https://www.scielo. br/j/mana/a/DL9zbpYpkmSMxhJvbHbKrWH/?format=pdf\&lang=pt Acesso em: 18 ago. 2021.

SOFSKY, Wolfgang. Tratado sobre la violencia. Madrid: Abada, 2006.

TAUSSIG, Michael. Belleza y violencia: una relación aún por entender. Popayán: Editorial Universidad del Cauca, 2014.

URIBE, María Victoria. El modelo chulavitas vs tipacoques en Colombia. In: Las guerras civiles de 1830 y su proyección en el siglo XX. Memorias de la Cátedra Anual Ernesto Restrepo Tirado. Museo Nacional de Colombia, Bogotá, 1998. p. 211-221. 